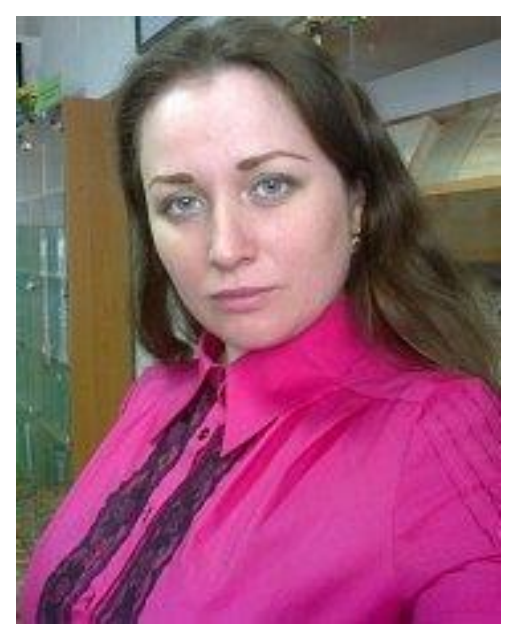

\title{
BONDUR
}

Tatyana A.,

Candidate of economic sciences, Leading researcher department of documentation for conservation and research funds of NSAL NAAS tanyabondur82@ukr.net

(Kyiv)

\section{AGRICULTURE - SCIENCE AND INDUSTRY AGROINDUSTRIAL PRODUCTION: A HISTORICAL PERSPECTIVE (MIDDLE OF THE XIX - EARLY XX CENTURY)}

The article highlights the contribution of individual Soviet scientists in the development of agriculture as a science and agriculture in the middle of the nineteenth - early twentieth century. In particular examines the works of eminent scholars A. Bolotov, D. Mendeleev, A. Sovietov, V. Dokuchaev, P. Kostychev, M. Sibirtsev, D. Pryanishnikov, M. Tulaykov, V. Williams, A. Zaykevych, A. Ismailsky, B. Rozhestvensky, A. Sokolovsky, A. Dushechkin. The basic trends in research affairs 90s of XIX - early XX century in the art of agriculture. It is noted that the contemporary structures of agrarian direction - research fields and agricultural societies - have made a great contribution to the development of a research case on agriculture, the most famous of which are Poltava, Kherson and Odessa experimental fields; Poltava, Kiev, Kharkiv Agricultural Societies.

Keywords: agronomy, industry, agriculture, chemicals, manufacturing, research station, soil fertility, yield crops.

\section{ЗЕМЛЕРОБСТВО - НАУКА І ГАЛУЗЬ АГРОПРОМИСЛОВОГО ВИРОБНИЦТВА: ІСТОРИЧНИЙ АСПЕКТ} (СЕРЕДИНА ХІХ - ПОЧАТОК ХХ СТОЛІТТЯ)

У статті висвітлено внесок окремих радянських вчених у розвиток землеробства як науки і галузі сільського господарства в середині XIX - на початку XX століття. Зокрема аналізуються прачі видатних науковиів А.Т. Болотова, Д.І.Менделєєва, О.В. Совєтова, В.В. Докучаева, П.А. Костичева, М.М. Сибіриева, Д.М. Прянишникова, М.М. Тулайкова, В.Р. Вільямса, А.С. Зайкевича, О.О. Ізмайльського, Б.М. Рожественського, О.Н. Соколовського, О.І. Душечкіна. Розкрито основні тенденщії у розвитку 
дослідної справи 90-х років XIX-початку ХХ століття в даній галузі аграрного виробництва. Зазначено, що великий внесок у розвиток дослідної справи по землеробству зробили тогочасні структури аграрного спрямування - дослідні поля та сільськогосподарські товариства, найвідоміші серед яких: Полтавське, Херсонське, Одеське дослідні поля; Полтавське, Київське, Харківське товариства сільського господарства.

Ключові слова: землеробство, галузь, сільське господарство, хімізачія, виробництво, дослідна станиія, родючість трунту, урожайність сільськогосподарських культур.

\section{ЗЕМЛЕДЕЛИЕ - НАУКА И ОТРАСЛЬ АГРОПРОМЫШЛЕННОГО ПРОИЗВОДСТВА: ИСТОРИЧЕСКИЙ АСПЕКТ}

\section{(СРЕДИНА ХІХ - НАЧАЛО ХХ ВЕКА)}

В статье освещен вклад отдельных советских ученых в развитие земледелия как науки и отрасли сельского хозяйства в средине XIX - начале ХХвека. В частности анализируются труды вылающихся ученых А.Т. Болотова, Д.И. Менделеева, А.В. Советова, В.В. Докучаева, П.А. Костычева, М.М. Сибириева, Д.Н. Прянишникова, М.М. Тулайкова, В.Р. Вильямса, А.Е. Зайкевича, А.А. Измаильского, Б.М. Рожественского, А.Н. Соколовского, А.И. Душечкина. Раскрыты основные тендениии в развитии исследовательской деятельности 90-х годов XIX - начала XX века в данной области аграрного производства. Отмечено, что большой вклад в развитие исследовательского дела по земледелию сделали тогдашние структуры аграрного направления - опытные поля и сельскохозяйственные общества, среди которых: Полтавское, Херсонское, Одесское опытные поля; Полтавское, Киевское, Харьковское общества сельского хозяйства.

Ключевые слова: земледелие, отрасль, сельское хозяйство, химизация, производство, исследовательская станиия, плодородие почвы, урожайность сельскохозяйственных культур.

At the present stage of the development of agrarian production in Ukraine, the concept of «agriculture» should be considered in two interrelated aspects of research - both social science and the branch of agriculture. Given the importance of agriculture as a science, one can speak of it as a doctrine of the rational use of land, its protection against degradation, and the regularities of reproduction of soil fertility in order to grow and obtain high and stable yields.

At the same time, agriculture as a branch of agricultural production combines crop production, fodder production, vegetable growing, fruit growing, and viticulture. The objectives of agriculture as an industry are: rational soil cultivation, regulation of 
agrophysical, agrochemical and biological processes in it, the provision of cultivated plants by all factors of life in the right ratio, the creation of conditions for stabilizing the soil fertility and the deficit-free balance of humus in it.

The purpose of the article is to reveal the historical aspects of the formation and development of agriculture as a science and industry.

The study of agriculture as a science and industry was devoted to the works of prominent scholars such as S. Antonets, P. Boyko, M. Gorodny, V. Gudz, M. Kravchenko, I. Primak, V. Sayko and others.

Agricultural science in the Russian Empire began to form in the middle of the XVIII century. First of all, it should be noted works of the outstanding Russian scientist M. Lomonosov (1711-1765). He boldly and decisively made materialistic ideas about nature. In contrast to the religious metaphysical views on the constancy of nature, M. Lomonosov in the famous work «About the layers of the earth» (1763) gave the first scientific description of the origin of black earth. M. Lomonosov was an active promoter of agricultural experience. He owns the translation into Russian of the book «Livonian Economy» (1747) on foreign experience in agriculture. At the same time, he was an opponent of the mechanical transfer of foreign experience to Russia, insisted on the need for the development of domestic agro-culture.

In addition, among prominent scientists in the field of agriculture in the middle of the XIX - early XX century it is possible to note the patriarchs of agricultural science such as A. Bolotov, D. Mendeleev, A. Sovetov, V. Dokuchaev, P. Kostychev, M. Sibirtsev, D. Pryanishnikov, M. Tulaikov, V. Williams, A. Zaykevich, A. Izmailsky, B. Rozhestvensky, A. Sokolovsky, A. Dushechkin and some others.

The purpose of this publication is to carry out a historical and scientific analysis of the process of formation and development of agriculture as a science and the field of agriculture, as well as the determination of the contribution of prominent agrarian scientists and agricultural organizational structures in the formation of scientific foundations of modern agriculture.

As noted above, the formation of agriculture as a branch of production with a scientific basis took a long historical time. An important place in this process was 
played by many Soviet scientists, among them the first Russian agronomist A. Bolotov (1738-1833). In 1771 he published his work «On the division of fields» (later it went on to extend its «On the division of land into seven fields»), in which he criticized the steam system of agriculture with one-sided grain direction. The crop rotation A. Bolotov considered a very important measure of farming. In one economy near Moscow, he introduced in 1774 the alternation of crops on the basis of the system developed by him, which provided for the alternation of crops: 1 - steam fertilizer; 2 - winter; 3 - the woods are «best» (wheat, barley, flax); 4 - the worst «worse» (oats, peas, buckwheat); 5-7 - flop. He was recommended to replace the natural overgrowth of the textures with herbs. He considered it necessary to carefully cultivate soil and fertilizer, attach great importance to grasshopper cultivation.

In the second half of the XIX century the development of capitalism in Russia began to develop the sugar industry, which led to the need to expand the crop of sugar beet. The development of capitalist relations put new demands on agronomic science. Currently, research is being conducted to address important issues of agricultural production. In 1867, under the guidance of the Russian chemist D. Mendeleev (1834-1907), experiments were first established for the purpose of studying the influence of fertilizers on the crop of crops. D. Mendeleev raised the question of the widespread introduction of such an event as the liming of acid soils and the use of phosphorous flour on these soils. And today deserve attention to his thoughts on soil cultivation, grassland, afforestation, irrigation, etc. [1].

K. Timiryazev (1843-1920) participated in experiments led by Mendeleyev, who, based on research, came to the conclusion of the great importance of deep plowing to combat drought. The scientist believed that the main task of scientific agriculture is to study the needs of plants and the ability to satisfy them. [2]. In addition, the scientist paid a lot of attention to studying the process of photosynthesis in plants. So, he found that photosynthesis is carried out in accordance with the law of conservation of energy; the intensity of photosynthesis is closely related to the intensity of light. Timiryazev expressed the opinion that chlorophyll not only physically, but also chemically participates in photosynthesis, thus foreseeing the 
development of modern science. Timiryazev also developed issues of water regime and mineral nutrition of plants; In introducing the achievements of plant physiology and agrochemistry in agricultural practice, the scientist saw the foundations of rational agriculture.

In the second half of the XIX century outstanding scholars A. Sovetov, I. Stebut, A. Engelhard, V. Dokuchaev, P. Kostychev, M. Sibirtsev and others.

A. Sovetov (1826-1901) - the first doctor of agriculture in Russia. In his scientific works, he highlighted the important issues of field grassland. And today, Sovetov's valuable statement is that the schemes of crop rotation should be developed for each particular farm. He cautioned against the pattern in the technologies of growing individual cultures [3].

I. Stebut (1883-1923) - Professor Petrovsky Agricultural Academy, who wrote many works on agriculture, agrochemistry, plant growing. He expressed the opinion on the importance of differentiated agricultural crops and the need for intensification of agricultural production [4].

A. Engelhard (1832-1893) did a lot to raise the culture of agriculture in the nonblack earth zone. So, scientists have been working on the use of phosphorous flour as phosphate fertilizers in the Smolensk province. He also attached importance to green fertilizers. He noted that phosphorous flour and sideration are the main methods for bringing the huge areas of the northern lands to the cultural state. A. Engelhard was an active advocate and advocate for the application of liming and mineral fertilizers in combination with organic fertilizers.

V. Dokuchaev (1846-1903) was the founder of scientific soil science. His most famous work is «Russian black earth» (1883). In it he examined in detail the distribution area, the way of origin, the chemical composition of the black earth, the principles of classification and methods of studying this soil. It was also proposed to define the soil as a special natural mineral-organic formation, and not any surface sediment (the concept of agro-geology) or arable layers (agronomy). Those or other soils are the result of the combined effect of the following factors: the living world, maternal breed, climate, relief and time. For the classification of soils, as well as for 
their rational use, it is necessary to proceed from the features of its origin (genesis), rather than chemical or granulometric composition. In his work, V. Dokuchaev turned to the causes of the increase in the frequency of droughts and damage to them, calling among these reasons the lack of proper methods of cultivating soils, crop rotation, measures for the preservation of moisture, deterioration of water and air regimes, erosion. [5].

P. Kostychev (1845-1895) is one of the founders of modern soil science. The main works of the scientist are devoted to the study of the biological basis of soil formation and ways to improve soil fertility. He showed that soil formation is a biological process associated with the development of vegetation and microorganisms, and that the task of soil science is to study soils in connection with the development of their vegetation. He first applied his knowledge in the field of microbiology to the study of the processes of decomposition of organic matter in the soil [6]. He was the author of the first in the empire of the textbook «Soil Science» and the original educational and popular science guide on agriculture - «The doctrine of soil fertility» (1884), «The doctrine of mechanical soil treatment» (1885), «Public guide to agriculture» (1884).

M. Sibertsev (1860-900) - talented student, close assistant and admirer Dokuchaev. Thanks to participation in expeditions, Sibertsev got the opportunity to practice the basic methods of soil determination, describe in detail and explore the whole complex of soil-forming factors. The results of the research and accumulated experience were one of the first works of the scientist «Chemical composition of vegetation and soil soils of the Nizhny Novgorod province» (1886). In this work he found himself an experienced scientist and soil scientist. He first collected and substantiated the results of chemical analyzes, suction properties and soil composition, and also gave them a definition. On the basis of the study of the results of field experiments - the data of the chemical analysis of the soil, the yield of the main field crops and the total estimation of soil Sibertsev proposed a new scale of soil boning. The researcher identified and characterized eight types of soils of different mechanical composition - black earths, podzolic soils, loams, sandy and sandy soils, 
as well as gave recommendations on their treatment and fertility. For the first time, the scientist identified dark-gray (transitional to black earths), gray and light gray (transient to northern loam) forest soils [7].

Of great importance in the development of agronomic science was the organization of research stations in Ukraine in the 90 years of the XIX century. The first experimental station was founded in 1884 in Poltava. In 1894, there were only nine institutions in the country that enjoyed constant assistance from loans from the Department of Agriculture and Rural Industry: Derebchinske experimental field; two experimental fields in the Kharkiv region; Poltava exploratory field, founded by the Poltava Agricultural Society; Vyatskiye experimental fields; research field of the Agricultural Society of Southern Russia. Most of the research fields devoted to the search and study of methods for increasing the efficiency of production in the field of plant growing. Among their tasks were: conducting experiments, observations and studies with crops of various crops, testing of new agricultural machinery, etc.

In particular, the Poltava field of research has made a number of conclusions that are valuable for practice in southern agriculture, the problems of soil moisture accumulation and preservation (by re-cultivating steam fields during the growing season), the identification of the most suitable for local conditions of perennial grasses (alfalfa), the choice of varieties of field crops, etc. The same institution conducted a series of experiments to find out the effect on crop yield crops of their alternation in crop rotation and the introduction of humus, time and depth of plowing, etc.

The results of the Kherson experimental field operations in the period from 1891 to 1900 became quite important data on the effect on the harvest of the terms of sowing and the density of grain crops, depth of plowing, methods of sowing, wrapping and care of crops, various steam cultivation and fertilization.

Other research stations of the Russian Empire paid no less attention to the study of issues of rational agriculture. Their invaluable merit to the country was to raise domestic agriculture to a qualitatively new level of development. 
After 1917, D. Pryanishnikov, M. Tulaikov, K. Gedroits, V. Williams and other prominent scholars who started scientific research at the end of the year before and at the beginning of the XX century continued to develop agricultural science.

Academician D. Pryanishnikov (1865-1948) is the author of the theory of the exchange of nitrogen compounds in the plant organism, the doctrine of the mineral nutrition of plants and the use of fertilizers. Beginning scientific work on the study of nitrogen exchange of plants, he throughout his life did not change this direction and entered the history of domestic biological science as a «biographer of nitrogen». Pryanishnikov identified the main task of agronomic chemistry as «the study of the cycle of substances in agriculture and the identification of those effects on the chemical processes occurring in the soil and plant, which can increase the yield or change its composition». Analyzing the experience of developed countries, he knew perfectly well that it is impossible to raise and stabilize yields without mineral fertilizers. The term «chemistry» was first used by them in 1924. The most outstanding work of the scientist is the textbook «Agrochemistry», published in 1934 [8].

An important contribution to agronomic science was made by Academician M. Tulaykov. Of great importance are his work on agriculture in the arid regions of the south-eastern regions of European Russia [9]. In particular, he developed a theory of fine soil cultivation, which contributes to better accumulation and preservation of moisture. He was the first to talk about the use of crop rotation in arid areas, laid the foundations of soil protection agriculture. The scientist studied methods of using salt mines, irrigation systems of the soil, conducted work to combat salinization in irrigation, organization and work of the largest agricultural research stations. His enormous experience, built on a concrete knowledge of the conditions and conditions of the grain economy, not only in our country, but also abroad, deserves it to be among the experts of agriculture in arid regions.

Academician V. Williams (1863-1939) made a great deal for the further development of scientific soil science. Valuable is his study of humus substances, the role of biological factors and soil formation processes. He has developed effective 
soil cultivation practices, ways to improve natural forage land, and so on. He noted that the soil fertility largely depends on the biological cycle of substances [10].

The work of Professor O. Doyarenko (1874-1958) played an important role in the development of the agro-physical field of agronomic research. The main scientific work of the scientist is devoted to the study of the influence of composition and properties of soils on the yield of agricultural crops. He improved the program of work of experimental fields, proved the influence of methods of growing field culture not only on the crop, but also on the main factors of the life of plants. It came to the conclusion that one of the reasons for low harvests in the non-black earth zone is the lack of air in the soil as a result of its improper cultivation. Established the basic principles of cultivating soil and turf. He developed techniques and constructed devices for the determination of physical and physical-chemical properties of the soil and the degree of use by field cultures of solar energy.

Professor of Kharkiv University A. Zaykevych (1842-1931) entered the history of agronomic science as initiator, organizer and one of the first theorists of agricultural research. It is also necessary to indicate the three main achievements of the scientist. First, it was established and substantiated that the possibility and expediency of fertilizing black soils has been proved. Secondly, it was pointed out the decisive importance of fertilizer regulations. Thirdly, the advantage of stringent mineral fertilizers was proved. Consequently, thanks to Zaykevych's activity, the scientific foundations of the modern conception of the fertilizer system were laid; black soil zone became in the Ukrainian provinces practically the first zone of application of mineral fertilizers. The professor analyzed and summarized the research on the action of various fertilizers: nitrogen, phosphorus, potassium, mixed, organic, as well as lime, gypsum. Professor Zaykevych's activities contributed to the creation of domestic sugar beet varieties, the organization of scientifically grounded breeding business (selection of wheat, potatoes, fodder crops) [11].

The well-known Ukrainian scientist O. Izmailsky (1851-1914) researched the soil moisture in the Kherson province and concluded that an important role of deep 
plowing in the fight against drought. He wrote that the moisture content of the soil depends on its type and structure no less than on the amount of precipitation [12].

B. Rozhestvensky (1874-1943) did a lot in the organization of research stations in Ukraine. He was the founder and first director of the Kharkiv research station. Much attention was paid to the development of a field research methodology for agricultural crops. He deserves the recognition of the positive effect of fertilizers, in particular phosphorus, in southern regions of Ukraine [13].

The works of O. Sokolovsky (1884-1959) are devoted to the study of the physical and chemical properties of the soil, the influence of exchange cations on the mechanical and water properties of the soil, the cultivation of podzolic and saline soils, the role of calcium in soil enrichment on the humus and fixation in the soil of mineral colloids and humus. He is the founder of colloid chemical technology soils, proposed a method of soil softening to combat water filtration in irrigation canals, ponds, and the like. He wrote a textbook on agricultural soil science «Course of Agricultural Soil Science» (1951).

Academician O. Dushechkin (1874-956) developed the scientific basis for the use of phosphate fertilizers in Ukraine, studied the nature of phosphoric acid compounds of the soil. He proposed to nourish winter nitrogen fertilizers early in the spring, which is now widely used in all areas of the country. Under his guidance, scientific studies of soils in the Uman region unfolded, ways of improving them and maintaining fertility were developed. He was one of the first researchers to pay attention to the problem of biological binding and mobilization of nutrients in the soil.

Consequently, the aforementioned prominent theorists and practices of agrarian science made an invaluable contribution to the development of both agriculture and domestic agriculture in general. It is on their scientific developments that the development of the modern branch of plant growing is also based.

Today, the development of agriculture is due to increased specialization in agricultural production and the progress of agricultural machines and tools associated with it. Conducting intensive scientifically grounded agriculture, adapted to current 
market conditions, requires highly productive use of suitable land for the cultivation of the most valuable and highly productive crops, varieties and hybrids, the wide introduction of effective fertility restoration measures taking into account the latest achievements of agricultural science and best practices.

\section{List of Literature}

1. Менделеев Д. И. Работы по сельскому хозяйству и лесоводству. Москва, $1954.620 \mathrm{c}$.

2. Тимирязев К. А. Избранные сочинения: научное издание. Москва : ОГИЗ, 1949. Т. 4. 472 с.

3. Советов А. Публичные лекции о сельском хозяйстве : научное издание. Санкт-Петербург : Тип. тов-ва «Общественная польза», 1862. $101 \mathrm{c.}$

4. Стебут И. А. Сборник статей по сельскому хозяйству : научное издание. Санкт-Петербург : Народная Польза, 1897. 228 с.

5. Докучаев В. В. К вопросу о переоценке земель европейской и азиатской России с классификацией почв 1898 г. Москва : Изд-во АН СССР, 1951. Т. 6. $595 \mathrm{c}$.

6. Костычев П. А. Почва, ее обработка и удобрение : практическое руководство : научное издание. Москва, 1912. 280 с.

7. Сибирцев Н. М. Об основании генетической классификации почв. Записки Ново-Александрийского института сельского хозяйства и лесоводства. 1885. Т. 9. № 2. С. 4-23.

8. Прянишников Д. Н. Избранные труды. Москва : Наука, 1976. 592 с.

9. Тулайков Н. М. Избранные произведения. Критика травопольной системы земледелия : сборник. Москва : Изд-во с.-х. лит., журналов и плакатов, 1963. $312 \mathrm{c.}$

10. Вильямс В. Р. Основы земледелия : научное издание. Москва : Гос. издво колхоз. и совхоз. лит-ры, 1940. 190 с.

11. Зайкевич А. Е. Задачи исследований в области культуры сахарной свеклы и их организация: научное издание. Харьков: А. Н. Гусева, бывш. В. С. Бирюкова, 1891.18 с.

12. Измаильский А. Значение культурных опытов в сельском хозяйстве. Вестник русского сельского хозяйства. 1893. № 30. С. 494-496.

13. Рожественский Б. Н. Главнейшие выводы полевых опытов 19131917 гг. Харьков : Изд. отдел Наркомзема УССР, 1922. 110 с.

\section{References}

1. Mendeleyev, D. I. (1954). Rabotyi po selskomu hozyaystvu i lesovodstvu [Works on agriculture and forestry]. Moscow. 620. [in Russian].

2. Timiryazev, K. A. (1949). Izbrannyie sochineniya [Selected works]. Moscow : OGIZ. 4. 472. [in Russian]. 
3. Sovetov, A. (1862). Publichnyie lektsii o selskom hozyaystve [Public Lectures on Agriculture]. Saint Petersburg. 101. [in Russian].

4. Stebut, I. A. (1897). Sbornik statey po selskomu hozyaystvu [Collection of articles on agriculture]. Saint Petersburg. 228. [in Russian].

5. Dokuchaev, V. V. (1951). K voprosu o pereotsenke zemel evropeyskoy $i$ aziatskoy Rossii s klassifikatsiey pochv $1898 \mathrm{~g}$. [On the question of the revaluation of European and Asian land with the classification of soils in 1898]. Moscow. 6. 595. [in Russian].

6. Kostychev, P. A. (1912). Pochva, ee obrabotka i udobrenie: Prakticheskoe rukovodstvo [Soil, its processing and fertilizer]. Moscow. 280. [in Russian].

7. Sibirtsev, N. M. (1885). Ob osnovanii geneticheskoy klassifikatsii pochv [On the basis of genetic classification of soils]. Zapiski Novo-Aleksandriyskogo instituta selskogo hozyaystva $i$ lesovodstva [Notes of the Novo-Alexandria Institute of Agriculture and Forestry]. 9, 2. 4-23. [in Russian].

8. Pryanishnikov, D. N. (1976). Izbrannyie trudyi [Selected Works]. Moscow. 592. [in Russian].

9. Tulaykov, N. M. (1963). Izbrannyie proizvedeniya. Kritika travopolnoy sistemyi zemledeliya [Selected works. Criticism of the grassland farming system]. Moscow. 312. [in Russian].

10. Williams, V. R. (1940). Osnovyi zemledeliya [Fundamentals of Farming]. Moscow. 190. [in Russian].

11. Zaikevich, A. E. (1891). Zadachi issledovaniy v oblasti kulturyi saharnoy sveklyi $i$ ih organizatsiya [The tasks of research in the field of sugar beet culture and their organization]. Kharkiv. 18. [in Russian].

12. Izmailsky, A. (1893). Znachenie kulturnyih opyitov $v$ selskom hozyaystve [The Importance of Cultural Experiences in Agriculture]. Vestnik russkogo selskogo hozyaystva [Bulletin of Russian Agriculture]. 30. 494-496. [in Russian].

13. Rozhestvensky, B. N. (1922). Glavneyshie vyivodyi polevyih opyitov 1913$1917 \mathrm{gg}$. [The main conclusions of the field experiments of 1913-1917]. Kharkiv. 110. [in Russian].

\section{Reviewer:}

Irina Borodai, Doctor of History, Professor

Received 15/03/2018 